Prace Filologiczne. Literaturoznawstwo 11(14) 2021

ISSN 2084-6045

e-ISSN 2658-2503

Creative Commons: Uznanie autorstwa 3.0 PL (CC BY)

DOI: $10.32798 /$ pflit.603

\title{
DWA PRZELOMY. WILHELM DILTHEY I HISTORYCZNOKULTUROWE PRZESŁANKI SCIENCE WARS
}

\author{
Two breakthroughs. Wilhelm Dilthey and the Historical \\ and Cultural Premises of Science Wars
}

\author{
DARIUSZ SEWERYN \\ Katolicki Uniwersytet Lubelski Jana Pawła II, Polska \\ E-mail: dseweryn@kul.lublin.pl \\ https://orcid.org/0000-0002-8170-6595
}

\begin{abstract}
The contemporary discrepancy between the humanities and the mathematical and natural sciences prompts a retrospective rethinking of the set of historical circumstances that have led to the breakdown of scientific life into isolated domains ('the two cultures', as C. Snow called it). As a result of this break-up, natural science mystifies the humanities, humanities mystify mathematical and natural sciences. The dispute dispute takes on an ideological colour, turning into a competition for a monopoly on the power to define reality.

In this context, Dilthey's concept of establishing the humanities as a kind of inversion of the natural sciences becomes perversely topical, all the more so, the influence of this concept on the self-definition of humanities. According to the approach presented in the article, Dilthey's postulate of the scientific sovereignty of humanistic research, completely independent from empirical and mathematical natural science, is in this approach an intermediate link between the two phenomena. The first is the escapist reaction of the artistic community to the seventeenth-century scientific revolution; the second - a conglomerate of such contemporary trends as sociological biophobia and anti-naturalism (aspects of cultural constructivism) or attempts to semiologize contemporary physical theories. Out of necessity, these tendencies are only roughly outlined here with the awareness that they themselves constitute a multifaceted research issue. Thus, in the article, Dilthey's philosophy of the humanities comes to the fore, especially those aspects that show a sufficiently clear analogy to the crisis of the $17^{\text {th }}$ century and at the same time submit to a sufficiently justified interpretation as one of the premises of the contemporary conflict of sciences.
\end{abstract}

Keywords: Wilhelm Dilthey, "the two cultures", science wars, philosophy of science 


\section{Streszczenie}

Współczesny rozdźwięk między humanistyką a naukami matematyczno-przyrodniczymi skłania do powtórnego przemyślenia zespołu historycznych okoliczności, które doprowadziły do rozpadu życia naukowego na odizolowane od siebie domeny (,dwie kultury” Charlesa Snowa). W efekcie tego rozpadu przyrodoznawstwo mistyfikuje humanistykę, humanistyka mistyfikuje nauki matematyczno-przyrodnicze; konflikt nabiera ideologicznego zabarwienia, przeradzając się w rywalizację o monopol na prawo do definiowania rzeczywistości.

W tym kontekście Diltheyowska koncepcja ugruntowania humanistyki jako poniekąd inwersji nauk przyrodniczych, w szczególności zaś wpływ tej koncepcji na autodefinicje dyscyplin humanistycznych - nabierają dosyć przewrotnej aktualności. Według przedstawionego w artykule ujęcia Diltheyowski postulat naukowej suwerenności badań humanistycznych, pozostających w całkowitej niezależności od empirycznego i matematycznego przyrodoznawstwa, stanowi ogniwo pośrednie między dwoma zjawiskami. Pierwszym jest eskapistyczna reakcja środowisk artystycznych na siedemnastowieczną rewolucję naukową; drugim - konglomerat takich współczesnych tendencji, jak socjologiczna biofobia i antynaturalizm (aspekty konstruktywizmu kulturowego) czy próby semiologizacji współczesnych teorii fizycznych. Tendencje te z konieczności zarysowane tu zostały jedynie szkicowo, ze świadomością, że same w sobie stanowią wielopłaszczyznowe zagadnienie badawcze. Tym samym na plan pierwszy wysuwa się w artykule Diltheyowska filozofia nauk humanistycznych, a zwłaszcza te jej aspekty, które wykazują dostatecznie wyraźną analogię z kryzysem XVII w. i zarazem poddają się dostatecznie uzasadnionej wykładni jako jedna z przesłanek współczesnego konfliktu nauk.

Słowa kluczowe: Wilhelm Dilthey, „dwie kultury”, science wars, filozofia nauki

Choć tak zwana hermeneutyka romantyczna, łączona z postacią Friedricha Schleiermachera, stanowiła poniekąd efekt uboczny protestanckiej myśli biblistyczno-teologicznej, to ugruntowała ona przeświadczenie, że wszelkiego rodzaju wytwory kultury umysłowej oferują wgląd w życie wewnętrzne autora. Samo pojęcie interpretacji zostało przeorientowane, ustanawiając czy odsłaniając wspólny grunt racjonalnych założeń i procedur o zakresie stosowalności szerokim na tyle, że mógł się nimi posłużyć teolog, filolog i historyk. Był to istotny krok na drodze do wykazania, że domena racjonalności nie ogranicza się do indukcyjnej, empiryczno-matematycznej metodologii nowożytnego przyrodoznawstwa. W tym kontekście, jako kontrprzykład, wystarczy przypomnieć, jak wielką rolę odgrywała w epoce przednowożytnej alegoreza - oraz techniki, które nazwać by można okołoalegorycznymi, jak euhemeryzm ${ }^{1}$ - uchodząca za najzupełniej racjonalną technikę (bo nie metodę) egzegezy: jej ofiarą, oprócz Biblii, padała zarówno grecka filozofia (zwłaszcza nurtu platońskiego), jak i grecko-rzymska „mitologia”, spektakularnie zneutralizowana przez inkluzję

${ }^{1} \mathrm{O}$ związkach alegorezy z euhemeryzmem vide D. Seweryn, Alegoria i problemy dyskursu symbolicznego, Lublin 2017, s. 141-179. 
do symbolicznego universum humanizmu. Dekonstrukcja mitów w wykonaniu Macieja Kazimierza Sarbiewskiego, który w traktacie Dii gentium przejechał po nich walcem kontrreformacyjnego symbolizmu, w finale zaś obłożył je uroczystą anatemą ${ }^{2}$, do dziś bywa traktowana jako wariant „humanistycznej egzegezy”, co ilustruje wage problemu.

Związki pojęcia interpretacji z rozwojem filologii są oczywiste; podstawy historyczno-lingwistycznej krytyki tekstu położyła już aleksandryjska szkoła filologiczna, lecz koncepcję, że interpretację w ogólności należy pojmować jako proces historyczny, sformułował dopiero Wilhelm Dilthey.

\section{1.}

Czasy Diltheya były epoką całkowitego odrzucenia heglizmu oraz apologii wiedzy doświadczalnej. Jedynym zatem sposobem oddania sprawiedliwości wiedzy historycznej zdawało się nadanie jej wymiaru naukowego porównywalnego z tą rangą, jaką zdobyły sobie nauki przyrodnicze. Tak więc Dilthey w odpowiedzi na pozytywizm postanowił obdarzyć nauki o kulturze epistemologią i metodologią równie godną szacunku jak ta, którą dysponowały nauki przyrodnicze $^{3}$.

Wyeksponowana przez Ricoeura zasługa Diltheya, polegająca na unaukowieniu dyscyplin kulturoznawczych, dla współczesnych historyków filozofii stanowi jednak kwestię uboczną, jeśli nie wręcz marginalną. Na plan pierwszy wysuwa się natomiast Diltheyowska „filozofia życia”.

Dążeniem Diltheya było [...] pogodzenie zantagonizowanych etosu i logosu, przezwyciężenie przepaści między zdolnością filozofii do wpływania na życie i kształtowania go a naukowym oglądem rzeczywistości. Filozofia więc miała być nie tylko twórczą siłą „kształtowania życia”, ale także kontemplatywnym oglądem jego rzeczywistości. Trzeba tu zauważyć, że wprowadzenie pojęcia „życia” w miejsce tradycyjnego pojęcia „bytu” miało właśnie na celu przezwyciężenie dualizmu „obcego” świata i poznającego go człowieka. „Życie” miało łączyć obydwie strony rzeczywistości: obiektywną i przeżywaną. Dziedzinę irracjonalnej filozofii życia, opanowanej genialnym wglądem i intuicją, nieskrępowaną przez dyscyplinę naukową, pragnął Dilthey pozyskać dla „ducha naukowego”. To przewodnie dążenie jego filozofii przedstawiać można $\mathrm{z}$ różnych perspektyw, jednak z pewnych ujęć tematycznych proponowałabym zrezygnować ${ }^{4}$.

${ }^{2}$ M. K. Sarbiewski, Dii gentium. Bogowie pogan, tłum. K. Stawecka, Wrocław-Warszawa-Kraków 1972, s. 576-577.

${ }^{3}$ P. Ricoeur, Język, tekst, interpretacja. Pisma wybrane, thum. P. Graff, K. Rosner, Warszawa 1989, s. 200.

${ }^{4}$ E. Paczkowska-Lagowska, Logos życia. Filozofia hermeneutyczna w kregu Wilhelma Diltheya, Gdańsk 2000, s. 180-181 (wyróżnienia w cytatach pochodzą z cytowanych tekstów, o ile nie zaznaczono inaczej). 
Do ujęć, z których cytowana autorka proponuje zrezygnować, należy właśnie „unaukowienie humanistyki”, częściej opatrywane etykietą „przełomu antypozytywistycznego". O ile jednak historykom filozofii łatwo z takiego ujęcia zrezygnować (z niewątpliwym pożytkiem dla ich dyscypliny), o tyle z punktu widzenia historii nauki - włączając $\mathrm{w}$ to również współczesną samoświadomość dyscyplin humanistycznych z jej technikami legitymizacji - takie łatwe to już nie jest. Tradycja hermeneutyczna - której składową jest zarówno Ricoeurowska ocena Diltheya, jak i autorskie kontrpropozycje Ricoeura dotyczące interpretacyjnej teorii oraz praktyki - nie jest może w dzisiejszych warunkach jakoś szczególnie produktywna explicite, niemniej została zinternalizowana wystarczająco głęboko, by oddziaływać pośrednio na pewne typy humanistycznych dyskursów, a zwłaszcza by dostarczać tym dyskursom środków ich naukowego uprawomocnienia. Już ta okoliczność wystarczyłaby dla uzasadnienia wniosku, że sprawa owego nieszczęsnego przełomu antypozytywistycznego nie jest całkiem zdezaktualizowana jako potencjalne zagadnienie badawcze. $Z$ tego punktu widzenia faktyczna recepcja Diltheya, którą historyk filozofii miałby prawo uznać za niepoprawną, jest nawet bardziej istotna aniżeli dążenie do rzetelnej eksplikacji jego myśli oraz fachowe dysputy w konwencji „o co mu tak naprawdę chodziło”. Inaczej mówiąc, interes historii filozofii, jakkolwiek z pewnością niesprzeczny $\mathrm{z}$ interesem refleksji metanaukowej, nie jest z nim tożsamy. Okoliczność, że do roli dyskursu metanaukowego pretendowała właśnie hermeneutyka filozoficzna, niczego w tym zakresie nie zmienia, wprost przeciwnie.

Natomiast okolicznością rozstrzygającą jest tutaj inny fakt, całkiem aktualny a nawet coraz bardziej aktualny, tzn. coraz mocniej rzutujący na współczesny status dyscyplin humanistycznych - mianowicie poszerzający się rozdźwięk między humanistyką a naukami matematyczno-przyrodniczymi. Problem ten został jasno i dobitnie przedstawiony przez Charlesa Snowa w książce The Two Cultures and the Scientific Revolution (1959), wydanej po polsku czterdzieści lat później ${ }^{6}$ w myśl zasady „lepiej późno niż wcale”.

Ostrość tego podziału jest na poziomie instytucjonalnym wciąż kamuflowana: w strukturach akademickich wydziały i katedry filozofii czy filologii współistnieją z wydziałami i katedrami nauk przyrodniczych, podtrzymując fikcję naukowej wspólnoty (unlimited community of enquirers, „,nieskończonej wspólnoty badaczy”, by przywołać klasyczną formułę Charlesa Peirce'a), która w kategoriach intelektualnych już od dawna nie istnieje („wspólnotę akademicką” realnie ustanawia jedynie jednolita siatka płac tudzież wspólna ministerialna lista „czasopism punktowanych”). Oczywiście przypisywanie odpowiedzialności za ten stan rzeczy

\footnotetext{
${ }^{5}$ Ibidem, s. 181.

${ }^{6}$ Ch. P. Snow, Dwie kultury, tłum. T. Baszniak, Warszawa 1999.
} 
akurat Diltheyowi byłoby nonsensem. Niemniej jego myśl odegrała pewną rolę w procesach, które do takiego stanu rzeczy doprowadziły. Niejakie wyobrażenie na ten temat dają nawet uwagi restytucyjne, jak ta, którą pod adresem Poppera formułuje Leszek Brogowski:

Jego dyskusja z Diltheyem na marginesie Wiedzy obiektywnej nie jest jedynie powierzchowna, ale też pozorna, jak gdyby autor walczył tam z chimerami, których pochodzenie trzeba komuś przypisać, aby tym jaskrawiej przedstawić i jaśniej uzasadnić własne stanowisko. Weźmy jeden przykład. Dilthey nie oddziela przepaścią, jak sądzi Popper, nauk humanistycznych od nauk ścisłych, przeciwnie - w Der Aufbau der geschichtlichen Welt in die Geisteswissenschaften (1910) wykazuje, że rozwiązania problemu epistemologicznego należy poszukiwać, wychodząc od paradygmatu nauk humanistycznych, a nie, jak wcześniej sądzono, udoskonalając w ich praktyce model nauk ścisłych. Taką drogą, mianowicie refleksji nad sposobem, w jaki rozum, w tym rozum naukowy, wpisuje się w strumień bieżącej codziennej świadomości - czyli właśnie tropem Diltheyowskim - podąży współczesna epistemologia ${ }^{7}$.

W odniesieniu do kwestii „Dilthey według Poppera” jest to przekonujące i oświecające sprostowanie, lecz w szerszym ujęciu rodzi dyskusyjne konsekwencje: może i tym Diltheyowskim tropem podąża współczesna epistemologia filozoficzna, ale już niekoniecznie współczesna meta-metodologiczna teoria nauki (scientific epistemology, epistemology of science), dla której prymarnym przedmiotem zainteresowania i układem odniesienia - czy to się komuś podoba, czy nie - jest raczej dziedzina matematyczno-przyrodnicza, czyli science w odróżnieniu od humanities i social studies, które w tym kontekście stanowią - by to ujać oględnie - przedmiot pomniejszej troski. Krótko mówiąc, w sporach między zwolennikami NOA (natural ontological attitude), deflacjonistami, konwencjonalistami, fikcjonalistami, redukcjonistami etc. ${ }^{8} \mathrm{z}$ trudem znajdziemy echa Diltheyowskiej tezy o prymacie humanistyki, bez trudu odnajdziemy natomiast odniesienia do Charlesa Sandersa Peirce'a, Alfreda Tarskiego, Willarda van Orman Quine'a, czyli do paradygmatu niespecjalnie humanistycznego.

Analogicznie przekonujące zastrzeżenia zgłasza Brogowski także pod adresem Heideggerowskiej czy Gadamerowskiej interpretacji Diltheya, co stanowić może godny uwagi przyczynek do zagadnienia: dlaczego z recepcją Diltheya coś poszło nie tak. Skądinąd, na poziomie elementarnym, wyjaśnienie jest dosyć trywialne: Heidegger, Gadamer, Popper posługiwali się krytycznymi odwołaniami do Diltheya dla własnych celów, czyli robili to, co zawsze robią filozofowie,

${ }^{7}$ L. Brogowski, Świadomość i historia. Studium o filozofii Wilhelma Diltheya, Gdańsk 2004, s. 176.

${ }^{8}$ Vide np. S. Psillos, Scientific Realism. How science tracks truth, London-New York 2005, s. $220-249$. 
gdy filozofująa . Ponieważ zaś interes badacza skupiającego się na Diltheyu jako temacie monograficznym jest odmienny, odczytanie typu monograficznego będzie, statystycznie rzecz biorąc, bardziej rzetelne, pełniejsze i lepiej wyważone. Stąd, gdy chcemy się dowiedzieć czegoś o Diltheyu jako Diltheyu, w istocie lepiej sięgnąć po książkę Ewy Paczkowskiej-Łagowskiej czy Brogowskiego lub choćby artykuł Włodzimierza Lorenca ${ }^{10}$ niż zdawać się na opinie hermeneutów, wznoszących swoje konstrukcje pojęciowe na rewizjonistycznych przesłankach, choćby nawet ten rewizjonizm nie był pozbawiony dobrych racji. Rzecz jasna przypuszczenie, że o źródłach hermeneutyki filozoficznej dowiemy się czegoś istotnego z pism Poppera, jest jeszcze mniej prawdopodobne.

Gdy natomiast bardziej interesuje nas kwestia rozpadu niegdysiejszej „wspólnoty badaczy", której najbardziej spektakularnym przejawem stały się współczesne science wars, wówczas wszelkie nawiązania do Diltheya jako patrona naukowej suwerenności studiów humanistycznych, ich nieskalanej niezależności względem zmatematyzowanego i zempiryzowanego przyrodoznawstwa, nabierają zupełnie innej wagi. Ujmując to z przeciwnej perspektywy, można zatem również powiedzieć, że jeśli - jak wynika $\mathrm{z}$ argumentacji kompetentnych historyków filozofii - z recepcją Diltheya coś rzeczywiście poszło nie tak, to przyczyny tego stanu rzeczy mogą leżeć, przynajmniej częściowo, w sformułowaniach, jeśli nie tezach, samego Diltheya.

2.

W terminach socjologii wiedzy kwestia Diltheyowskiej specyfikacji „nauk o duchu" staje się uchwytna jako problem naukowego uprawomocnienia humanistyki.

W odróżnieniu od osiągnięć uzyskiwanych w domenie science efekty badań prowadzonych $\mathrm{w}$ dziedzinie humanities i social studies nie podlegają testowaniu w trybie interaktywnym. Profile lotnicze można sprawdzić w tunelu aerodynamicznym, do testowania leków używa się dwóch grup kontrolnych, z których pierwsza przyjmuje aktywny związek chemiczny, a druga placebo. Niczego podobnego nie można przeprowadzić w przypadku tez i modeli oferowanych przez dyscypliny humanistyczne. Wartościowanie osiągniętych efektów przebiega tu wedle całkiem odmiennych zasad, ponieważ źródłem informacji zwrotnej nie jest interakcja z przedmiotem, lecz interakcja ze środowiskiem

${ }^{9}$ Skądinąd relacja Dilthey-Heidegger bywa postrzegana zarówno w kategoriach continuum, jak i przeciwnie. Oba ujęcia można zresztą pogodzić, jak to czyni Leszek Brogowski: „Heidegger wiele filozoficznych pomysłów zaczerpnął [...] właśnie od Diltheya. Odrzucając pracę historyków i historyków filozofii, Heidegger oczyszczał przed swoją myślą pole, na którym tworzył potem własne, nieliczące się z historyczną rzeczywistością interpretacje tradycji filozoficznej. Tak pojętą poezję pojęć nazywa (się odtąd) filozofią" (L. Brogowski, op. cit., s. 9; vide też s. 16).

${ }^{10}$ W. Lorenc, Filozofia życia Wilhelma Diltheya, „Sztuka i Filozofia” 2005, t. 27, s. 31-45. 
społecznym (vide klasyczna formuła: „Referat pana/pani X został dobrze przyjęty"; proweniencja tej konwencji aksjologii stosowanej sięga co najmniej Wersalu z czasów Ludwika XIV). Prawomocność dowodu matematycznego nie opiera się na statystyce uznania; siła teorii fizycznej mierzona jest jakością przewidywań, jakich ta teoria dostarcza; wartość teorii konstruowanych w domenie dyscyplin humanistycznych szacuje się zupełnie inaczej. Dlatego dyscypliny te wymagają dodatkowej legitymizacji.

Nagród Nobla nie przyznaje się w takich dziedzinach jak socjologia, filozofia czy historia sztuki; hierarchiczne pozycjonowanie dyscyplin naukowych jest faktem społecznym, który - tak jak inne zinstytucjonalizowane fakty społeczne - wykracza poza kompetencje filozoficznej epistemologii. Z tego między innymi powodu (auto)refleksja metodologiczna odgrywa w pracach typu humanistycznego nieporównanie większą rolę aniżeli w badaniach matematyczno-przyrodniczych; w skrajnym przypadku, tj. w naukach matematycznych, metodologia jest w zasadzie nieodróżnialna od korpusu dyscypliny. I właśnie ta dysproporcja zapotrzebowania na metodologiczne ugruntowanie operacji badawczych jest znacznikiem - niejedynym - rzeczywistego zapotrzebowania humanistyki na społeczną legitymizację. Dilthey nie był socjologiem, lecz zdawał sobie z tego sprawę.

Cokolwiek by na ten temat sądzili filozofowie, Diltheyowskie Geisteswissenschaften wciąż pozostają w zasobach systemu uprawomocnien, do jakiego odwołują się, jawnie lub implicite, zwłaszcza nauki o literaturze. $\mathrm{Z}$ tego względu analiza proweniencji „Zwrotu antypozytywistycznego” w nieco poszerzonych kategoriach nie jest przedsięwzięciem ani jałowym, ani anachronicznym. Krótko mówiąc, to nie do filozofii należy rozstrzyganie, w jaki sposób myśl Diltheya wpisuje się w historię nauki - nemo iudex in causa sua.

„Filozofia według niemieckiego hermeneuty nie skupia się na jednej części rzeczywistości, jak nauki szczegółowe, ale ogarnia całokształt” ${ }^{11}$ - oznajmia autorka artykułu o Diltheyowskim pojęciu interpretacji. Nie jest to wszakże bynajmniej specyfika stanowiska Diltheya - to raczej ogólnofilozoficzny (resp. ontologiczno-epistemologiczny) komunał czy, gdyby ktoś wolał, topos. Sam Dilthey bywał bardziej powściągliwy, jeśli idzie o owo roszczenie filozofii do „ogarniania całokształtu”: zdawał sobie sprawę, w jak niewygodnej pozycji znalazła się filozofia w efekcie wyodrębnienia się z niej nauk szczegółowych ${ }^{12}$. Dlatego właśnie widział potrzebę określenia na nowo zadań tej dyscypliny.

${ }^{11}$ M. Markowska, Interpretacja jako rozumienie w ujęciu Wilhelma Diltheya, „Czasopismo Filozoficzne" 2007, nr 2, s. 73.

${ }^{12}$ Vide W. Dilthey, O istocie filozofii, thum. E. Paczkowska-Łagowska, Warszawa 1987, s. 19-20. 
Tak oto ze stosunku filozofii do rozmaitych dziedzin ludzkiego życia wynika jej prawo nie tylko do ugruntowania i powiązania wiedzy o nim z naukami szczegółowymi, w których ta wiedza się utrwaliła, lecz także prawo opracowania tych dziedzin w szczegółowych dyscyplinach filozoficznych, jak filozofia prawa, filozofia religii, filozofia sztuki. [...] Jest także oczywiste, że każda taka teoria, która zamiast czerpać z samego materiału opiera się na treściach podawanych przez nauki szczegółowe i tylko fragmentarycznie je sprawdza, nie ma prawa do istnienia. Jednakże wobec ograniczoności sił ludzkich jedynie w rzadkich przypadkach badacz z zakresu dyscypliny szczegółowej zdoła w sposób tak pewny opanować logikę, epistemologię i psychologię, by teoria filozoficzna nie mogła już wnieść niczego nowego ${ }^{13}$.

Symptomatyczne jest jednak w tym wywodzie przejście do porządku nad problemem komplementarnym. Zaznaczywszy bowiem nikłość prawdopodobieństwa, iżby przedstawiciel dyscypliny szczegółowej zdołał sobie przyswoić fachowe kompetencje filozoficzne, autor nie zauważył, że ten argument można łatwo odwrócić: filozof, „wobec ograniczoności sił ludzkich”, nie jest w stanie opanować całego spektrum dyscyplin szczegółowych na poziomie, który pozwoliłby mu na swobodną dyskusję $\mathrm{z}$ lingwistą, teoretykiem literatury, socjologiem, biologiem, kosmologiem etc. na poziomie merytorycznym, by niezbicie dowieść wszystkim razem i każdemu z osobna, jak fałszywe jest mniemanie, jakoby „teoria filozoficzna nie mogła już wnieść niczego nowego”. Obecnie, u progu drugiego dwudziestolecia XXI w. kwestia ta rysuje się znacznie, ale to znacznie ostrzej aniżeli w czasach Diltheya (wystarczy wspomnieć choćby mnogość interpretacji mechaniki kwantowej). Tymczasem w debatach toczonych w kontekście science wars wciąż przewija się anachroniczna argumentacja czerpana z Heideggerowskiej i Gadamerowskiej hermeneutyki, która głosiła, że współczesne, sformalizowane przyrodoznawstwo stanowi projekcję „postawy teoretycznej" z właściwymi jej alienacyjnymi ograniczeniami, od których wolna pozostaje filozoficzna ontologia, nabywająca tym samym - po nader niskich kosztach - uprawnień do objaśniania przyrodoznawcom, jaki jest właściwie przedmiot ich badań i dlaczego jest on nie do końca rzeczywisty, a w każdym razie znacznie mniej rzeczywisty niż im się zdaje.

Na styku z kategoriami, metodami, kryteriami współczesnej nauki (science) humanistyka potrafi czasem przybierać pozę, za którą skrywa się mieszanina szczerej ignorancji oraz nieczystego sumienia. Pozie tej odpowiadają po stronie science kuriozalne niekiedy wyobrażenia na temat humanities i social studies pożywką dla tych wyobrażeń stają się ekscesy konstruktywizmu społecznego, przeczącego, iżby teorie przyrodoznawstwa były w jakiejś istotnej mierze determinowane przez samą przyrodę. Tym, czym jest społeczny konstruktywizm

\footnotetext{
${ }^{13}$ Ibidem, s. 106.
} 
(vel socjologiczny determinizm) w stosunku do nauk fizycznych, tym jest enwironmentalizm w stosunku do biologii: negacja ewolucjonistycznego uwarunkowania wzorców behawioralnych; przeświadczenie o nieograniczonej plastyczności ludzkich cech i zachowań; krytyka psychologii ewolucyjnej za pomoca nieodpartego argumentu, że szkodzi ona w zbożnym dziele eliminacji toksycznego konstruktu kulturowego, jakim jest binarna kategoria płci. Antyteza: „socjologiczna biofobia i antynaturalizm” contra ,biologia i empiryczno-matematyczna fizyka" nie jest oczywiście sprowadzalna do antytezy: Geisteswissenschaften contra Naturwissenschaften, lecz by twierdzić, że między jedną a drugą dychotomią nie zachodzi żaden historyczny związek, trzeba sporo epistemologicznego wyrafinowania albo po prostu złej wiary.

W efekcie rozpadu życia naukowego na „dwie kultury” przyrodoznawstwo mistyfikuje humanistykę, humanistyka mistyfikuje nauki matematyczno-przyrodnicze, a dysputa „międzykulturowa” nabiera ideologicznego zabarwienia, przeradzając się w rywalizację o monopol na prawo do definiowania rzeczywistości. W tym kontekście Diltheyowska koncepcja ugruntowania humanistyki jako poniekąd inwersji nauk przyrodniczych nabiera dosyć przewrotnej aktualności.

3.

Komentując stan rzeczy, jaki wytworzył się kilkadziesiąt lat po wystąpieniu Schleiermachera, Wilhelm Dilthey miał już podstawy, by z ufnością spoglądać w przyszłość:

Dziś hermeneutyka występuje w kontekście nowych istotnych zadań humanistyki. Broniła ona zawsze pewności rozumienia przed sceptycyzmem historyka i subiektywną dowolnością. Najpierw, kiedy zwalczała wykładnię alegoryczną, potem gdy, wbrew sceptycyzmowi soboru trydenckiego, uzasadniała - doniosła to doktryna protestancka - możliwość zrozumienia pism biblijnych bez wychodzenia poza ich tekst; i jeszcze później, gdy wbrew wszelkim wątpieniom w poczynania Schlegla, Schleiermachera i Boeckha teoretycznie uzasadniała perspektywy rozwojowe nauk filologicznych i historycznych ${ }^{14}$.

Hasło Schleiermachera - ,śmiałe zdanie”15, jak powiadał Dilthey - „rozumieć autora lepiej niż on sam siebie rozumiał" w dalszej perspektywie okazało się jednak wkroczeniem na równię pochyłą.

${ }^{14}$ W. Dilthey, [Rozumienie] (Das Verstehen anderer Personen und ihrer Lebensäusserungen, w: idem, Gesammelte Schriften, t. 1-19, Stuttgart-Göttingen 1958-1982, t. 7), cyt. za: idem, Wybór pism, w: Z. Kuderowicz, Dilthey, Warszawa 1987, s. 230. Vide także W. Dilthey, Powstanie hermeneutyki, w: idem, Pisma estetyczne, tłum. K. Krzemieniowa, oprac. Z. Kuderowicz, Warszawa 1982, s. 304-310.

${ }^{15}$ W. Dilthey, [Rozumienie], s. 230. 
Wilhelm Dilthey, który doktoryzował się na podstawie rozprawy o etyce Schleiermachera w roku 1864, wyszedł ze słusznego założenia, że życie jako proces kulturowy cechuje zasadnicza autonomia względem świata fizycznego. Wynikało stąd trafne wskazanie, że metodologia badań przyrodniczych w ogólności a zwłaszcza, zauważmy, w ówczesnym jej stanie - nie ma do zaoferowania narzędzi użytecznych dla studiów nad rzeczywistością kulturową. Przeciw idealistycznej hipostazie „natury ludzkiej” zwracało się stwierdzenie: „Człowiek jako fakt poprzedzający historię i społeczeństwo jest fikcją genetycznej interpretacji; ten zaś człowiek, który jest obiektem zdrowej analitycznej wiedzy, stanowi indywiduum pojmowane jako część składowa społeczeństwa"16. So far so good. $\mathrm{W}$ istocie rozwaga uczonego rozciaggała się nawet dalej, zaznaczał on bowiem swój sprzeciw wobec psychologicznego redukcjonizmu:

[...] historia literatury i poetyka mają do czynienia jedynie ze stosunkiem uchwytnego zmysłowo połączenia słów do tego, co one wyrażają. I co jest tu najistotniejsze: wyrażaną w ten sposób treścią nie są procesy przebiegające $\mathrm{w}$ psychice poety, lecz pewien układ stworzony przez te procesy, ale dający się wyodrębnić. [...] Zatem przedmiot, z którym przede wszystkim ma do czynienia historia literatury lub poetyka, jest czymś innym niż procesy zachodzące w psychice poety lub czytelników. Realizowany jest tu związek duchowy, który wkracza w świat zmysłowy, ale rozumieć go możemy tylko wycofując się z tego ${ }^{17}$.

Celem było wyspecyfikowanie nowej grupy dyscyplin naukowych z właściwym jej zakresem odniesienia:

Te przykłady wyjaśniają, co tworzy przedmiot nauk, o których mówimy, na czym w związku z tym polega ich istota i co odgranicza je od nauk przyrodniczych. Przedmiotem tych nauk również nie są wrażenia, tak jak występują one w przeżyciach, ale obiekty, jakie tworzy poznanie, aby te wrażenia uczynić materiałem dla swych konstrukcji. W obydwu rodzajach nauk zatem przedmiot tworzony jest zgodnie z prawem samych faktów. W tym zgodne są obydwie grupy nauk. Ich różnica leży w tendencji, z jaką tworzony jest ich przedmiot, w postępowaniu, które owe grupy konstruuje. Tam w rozumieniu powstaje obiekt duchowy, tu w poznaniu przedmiot fizyczny ${ }^{18}$.

Operacjonistyczna definicja, oparta na dystynkcji między poznaniem a rozumieniem, prześlizgiwała się jednak chyłkiem obok całego zestawu trudności; skała, na której uczony wzniósł swój kościół „nauk o duchu”, aby bramy piekielne nauk przyrodniczych go nie przemogły, nie była jednak aż tak monolityczna, jak głosili (i głoszą) najwierniejsi akolici.

${ }^{16} \mathrm{~W}$. Dilthey, [Psychologia, antropologia a humanistyka] (Einleitung in die Geisteswissenschaften, ks. I, rozdz. VIII, w: idem, Gesammelte Schriften, t. 1), w: idem, Wybór pism, s. 200.

${ }^{17}$ Idem, [Określenie „nauk o duchu”] (Der Aufbau der geschichtlichen Welt in den Geisteswissenschaften, w: idem, Gesammelte Schriften, t. 7), w: idem, Wybór pism, s. 188.

${ }^{18}$ Ibidem. 
Nie jest bynajmniej rzeczą oczywistą, że w świecie duchowym istnieją przedmioty (a nie raczej, na przykład, energie); co to przedmiot, poucza nas doświadczenie empiryczne i społeczne, mamy też pojęcie obiektów (przedmiotów) matematycznych, których przedmiotowość ma tę szczególną cechę, że możemy nimi efektywnie operować nawet wtedy, gdy nie mamy wyrobionej opinii na temat ich ontologicznego statusu. Mamy jeszcze tradycyjny „przedmiot materialny” i ,przedmiot formalny” w staroświeckiej metodologii nauk oraz „,przedmiot intencjonalny" fenomenologii. Gdzieś pomiędzy tymi wszystkimi przedmiotami tkwi Diltheyowski przedmiot duchowy, podczas gdy sam duch lokuje się w szczelinie między empiryczną psychiką a empiryczną przyrodą; nie jest to umiejscowienie komfortowe.

Ale fundamentalna różnica, nad którą Dilthey przeszedł do porządku, nie leży tylko w tendencji (czy, w terminach fenomenologicznych, intencji), z jaką przedmiot jest tworzony. Różnica ta polega na tym, że konstrukcjonistyczny aspekt przyrodoznawstwa pozostaje ostro ograniczony obiektywną regularnością badanych przez nie zjawisk. Cykl dobowy podlegał rozmaitym eksplikacjom (rydwan Heliosa; obrót Słońca wokół Ziemi; obrót Ziemi wokół osi), ale wszystkie one opierały się na wspólnych danych obserwacyjnych. Pora wschodu i zachodu Słońca nie była zależna od tego, czy obserwator czuł się heliocentrystą, geocentrystą, czy też raczej czcicielem Atona albo Heliosa. Przyrodoznawcy już od połowy XVIII w. stali się przysłowiowymi gentlemanami - zwykle nie spierali się o fakty (bo te można było łatwo sprawdzić), spierali się o teorie; przedstawiciele „nauk o duchu” o fakty musieli się spierać nieustannie; czynią to zresztą do dzisiaj. Ścisła faktualność tematów humanistycznych kończy się zwykle na źródłach (np. faktem dotyczącym stosunków Bolesława Śmiałego z biskupem Stanisławem jest enigmatyczna zapiska Galla oraz zawartość późniejszych tekstów hagiograficznych; transformacja tych danych w spójną sekwencję „zdarzeń historycznych" to kwestia fabularno-narracyjnych preferencji, w tym wyboru komparatystycznych odniesień; z tego oczywiście nie wynika, jakoby wszystkie hipotetyczne rekonstrukcje tej sekwencji były tyle samo warte, choć ich aspiracje do faktyczności muszą pozostać ograniczone).

Rozumienie ustanawia przedmiot duchowy; poznanie ustanawia przedmiot materialny. Tak zdefiniowane przedmioty są względem siebie „ortogonalne” nie mają żadnego wzajemnego odniesienia. A ponieważ tak zdefiniowany obiekt duchowy ma status zarazem ontologiczny i metodologiczny, to wynika stąd, że treści kulturowe mogłyby się doskonale obejść bez jakiegokolwiek fizyczno-społecznego świata.

I rzeczywiście się obchodzą. Wyzwalając ducha z natury, uczony nie zawahał się uwolnić zarazem twórczości artystycznej od ciężaru powiązań z rzeczywistością - zarówno fizyczną, jak i społeczną. 
Zajmiemy się teraz działaniem fantazji, dzięki któremu kształtuje się drugi świat, różny od świata naszych poczynań. [...] W życiu [...] tworzy ona świadomie drugi świat, w którym człowiek usiłuje uwolnić się od krępującej go rzeczywistości: tym światem jest gra, w której odświętność potęguje istnienie; maskarada, przebranie, świąteczny korowód kreują świat różny od codziennej egzystencji. Epoka rycerska i dworska kultura renesansu pokazują, w jaki sposób już w łonie samego życia tworzy się świat poetycki, zupełnie od tego życia oderwany. Podobnie kształtowany jest różny od doświadczalnej rzeczywistości świat tworów fantazji religijnej. [...] Początkowo w mitach i wierze w bóstwa ta religijna siła wyobraźni wiąże się z wymogami życia. W miarę rozwoju kultury oddziela się ona stopniowo od potrzeb religijnych i owemu drugiemu światu nadaje znaczenie samodzielne, jak to widać na przykładzie Homera, tragików greckich, Dantego czy Wolframa von Eschenbach. Poezja zaś zupełnie uwalnia ponadzmysłowy religijny świat od więzów narzuconych mu przez nasze cele i potrzeby życiowe ${ }^{19}$.

Przed koncepcją, wedle której poezja wyraża życie dzięki zupełnemu oderwaniu „świata poetyckiego” od życia, nieuchronnie wyłania się problem zasady reprezentatywności (odwrotność zasady indywiduacji). Przejście od eskapistycznej genezy do reprezentatywnej funkcji literatury - jej „nasycenia pierwiastkiem ogólnym"20 - okazuje się u Diltheya oparte na założeniu tyleż prostym, co dalekim od oczywistości: „,...] w ludzkim świecie na skutek działania ogólnych stosunków społecznych i zachowań psychicznych nie ma indywiduum, które nie byłoby zarazem z różnych względów reprezentatywne, nie ma losu, który nie byłby pojedynczym przykładem jakiegoś ogólniejszego typu kolei życiowych" ${ }^{21}$. Ta egalitarystyczna, jeśli nie populistyczna wręcz, teza zestawiona z rzeczywistością praktyki literackiej traci wiarygodność. Mogą to zilustrować dwa przykłady.

Pierwszy dowodzi, że na gruncie owej tezy ironia romantycznego poematu dygresyjnego stawałaby się nieczytelna i właściwie bezpodstawna:

Ja sam się dziwię, że za bohatéra

Wziąłem takiego prostego szlachcica!

Oto pierwszy raz swe usta otwiéra

Przed swą kochanką, która w nów księżyca

Swe włosy czarnobłękitne ubiéra

Jakby sawantka albo czarownica,

I słyszy - że nie jak wieszcz lub astronom

Kochanek wita ją - lecz jak ekonom ${ }^{22}$.

${ }^{19}$ Idem, [Fantazja poetycka] (Das Erlebnis und die Dichtung, Berlin 1907), w: idem, Wybór pism, s. 264-265.

${ }^{20}$ Ibidem, s. 266.

${ }^{21}$ Ibidem.

${ }^{22}$ J. Słowacki, Beniowski, Pieśń I, w. 545-552; cyt. według edycji: idem, Dzieła wszystkie, t. 5, red. J. Kleiner, Wrocław 1954. 
Jest to komentarz do epizodu, w którym

Beniowski myślał, że anioł, i witał

Jak bóstwo: długim, przeciągłym westchnieniem,

Potém się zmięszał i o zdrowie spytał -

Co dziś byłoby wielkim uchybieniem!

Nieświatowością! znakiem, że nie czytał

Pani Sand, że się byronicznym cieniem

Nie okrył, że jest niezgrabny w rozmowie,

Że nie wie, jak to mówić romansowie ${ }^{23}$.

To właśnie demonstracja literackiej techniki tematyzowania pospolitości aby ją wyartykułować, trzeba się odwołać do jej przeciwieństwa (ironia Słowackiego jest tu piętrowa: wszak historycznym pierwowzorem owego „zwykłego szlachcica" był zupełnie niezwykły węgiersko-polsko-francuski awanturnik). Ten sam wzorzec, w zupełnie innej konwencji stylistyczno-gatunkowej, wykorzystuje Elegy Written in a Country Churchyard Thomasa Graya:

Some village-Hampden, that with dauntless breast

The little tyrant of his fields withstood;

Some mute inglorious Milton here may rest,

Some Cromwell guiltless of his country's blood.

The applause of listening senates to command,

The threats of pain and ruin to despise,

To scatter plenty o'er a smiling land,

And read their hist'ry in a nation's eyes,

Their lot forbade $[\ldots]^{24}$.

Pospolite, typowe, niczym niewyróżniające się żywoty, mimo całej okazywanej im przez narratora sympatii, jako literacki temat nie mają własnej substancji można im ją nadać tylko przez kontrast: barwnie wykładając, czego to mianowicie their lot forbade ('los im odmówił'). Słowem, empiryczna rzeczywistość literatury dostarcza łatwo dostępnych dowodów, że Diltheyowski Everyman „nie ma indywiduum, które nie byłoby zarazem z różnych względów reprezentatywne" - jest okazjonalnym konstruktem, pozwalającym przeskoczyć rozpadlinę pomiędzy rzekomo samosterownym „światem poetyckim” a rzeczywistością wzorców społecznych i wymogów technicznych literackiego dyskursu. Zresztą świadectwem złej wiary, z jaką ów idealistyczny egalitaryzm został okazjonalnie wprowadzony, jest romantyczna apoteoza poetyckiej indywidualności,

${ }^{23}$ Ibidem, w. 537-544.

${ }^{24}$ Th. Gray, Elegy Written in a Country Churchyard, w. 57-65, cyt. według: Antologia liryki angielskiej, oprac. J. Pietrkiewicz, Warszawa 1987, s. 120, 122. 
która to indywidualność jest dla Diltheya tyleż przyczyną sprawczą, co i samym tematem twórczości artystycznej.

Poeta zatem różni się od wszystkich innych klas ludzi bardziej, niż skłonni jesteśmy przypuszczać. A więc wbrew filisterskiemu mniemaniu, opartemu na zacnej przeciętności w zakresie poetyckiego rzemiosła, będziemy musieli przyzwyczaić się do tego, by impulsy wewnętrzne i zachowanie się tych demonicznych natur ujmować z perspektywy ich szczególnej organizacji, a nie na miarę przeciętności normalnego człowieka ${ }^{25}$.

Wspólnotę rozumienia, czyli normalizację związku między indywidualną ekspresją a jej odwzorowaniem w przeżyciu odbiorcy, ustanawia i gwarantuje empatia (Mitfühlen): „Na gruncie przeżywania i rozumienia samego siebie i w stałym ich oddziaływaniu na siebie kształtuje się rozumienie innych osób i ich ekspresji życiowych"26. Już Mickiewicz był bardziej krytyczny, kończąc ostatni sonet cyklu odeskiego sarkastycznie urwanym wersem: „Taki wieszcz jaki słuchacz”27.

Wprawdzie „przeżywanie jest interioryzacją (Innewerden) rzeczywistości”"28, ale w Diltheyowskiej teorii rozumienia sama rzeczywistość jawi się zasadniczo jako persona non grata:

Przedmiotem rozumienia jest zawsze to, co jednostkowe. [...] z analizy przeżycia i rozumienia nas samych wynika, że to, co jednostkowe, jest w świecie duchowym wartością samoistną, a nawet jedyną wartością samoistną, którą możemy niewątpliwie stwierdzić. A zatem to, co jednostkowe, interesuje nas nie tylko jako przykład wartości ogólnoludzkich, ale jako indywidualna całośćc 29 .

Ostatecznym horyzontem operacyjnym humanistyki okazuje się zatem, w tym ujęciu, studium przypadku. Problem tej teorii nie leży w jej niedopracowaniu; wiemy, że Gadamer i Ricoeur wskazali środki pozwalające przynajmniej przekroczyć taki psycho-personalizm. Ale dopiero spojrzenie historyczne pozwala uczynić ową teorię rozumienia przedmiotem rozumienia oraz - nie bójmy się tego słowa - przedmiotem wyjaśnienia. Teza jest następująca: już u historycznych podstaw współczesnej humanistycznej samoświadomości metodologicznej natrafiamy na lęk przed empiryczno-matematycznym paradygmatem wiedzy i nie jest to zjawisko niemające precedensu. W odniesieniu do kultury literackiej XVII w. już w roku 1978 diagnozowała je Jadwiga Sokołowska.

${ }^{25}$ W. Dilthey, [Fantazja poetycka], s. 267. Z ideą psychologicznej osobliwości artystów rozprawiła się na gruncie psychologii, już dość dawno temu, Danuta Danek, vide eadem, Nauka o literaturze a psychologia, w: Autor, podmiot literacki, bohater, red. A. Martuszewska, J. Sławiński, Wrocław-Warszawa-Kraków 1983, s. 14-16.

${ }^{26}$ W. Dilthey, [Rozumienie], s. 214.

${ }^{27}$ A. Mickiewicz, Ekskuza, w: idem, Dzieła wszystkie, t. 1: Wiersze, cz. 2, red. K. Górski, Wrocław-Warszawa-Kraków 1972, w. 14, s. 16.

${ }^{28}$ W. Dilthey, [Rozumienie], s. 230.

${ }^{29}$ Ibidem, s. 223. 
4.

Ludziom XVII wieku nauka i filozofia - ukazując rzeczywistość jako nieustający ruch jednolitej materii - odebrały poczucie ładu i pewnej stabilizacji w istniejącym świecie. [...] Człowiek baroku znalazł się w sytuacji, w której nie tylko usunięto mu ziemię spod nóg, ale jednocześnie pozbawiono zdolności widzenia. Trudno się dziwić rozpaczliwym próbom szukania ratunku w religii i w sztuce.

W baroku następuje olbrzymi rozwój matematyki, a wraz z nią mechaniki. [...] Zwrot do bezpośredniego, eksperymentalnego badania rzeczywistości był warunkiem unowocześnienia nauki, z czego zadawano sobie sprawę, ostro rozprawiając się z przemożnymi autorytetami przeszłości, z których najpoważniejszy był autorytet Arystotelesa. [...] Matematyka wpłynęła zasadniczo na pojęcie przedmiotu badań naukowych - przedmiot ten przestał być jakością, stał się ilością, którą się mierzy, waży, liczy.

Drugą, obok matematyki, nauką, która w XVII w. odsłoniła nie przeczuwane dotychczas perspektywy, była mechanika, uważana niemal za królową nauk. Jej przyznawano niekiedy palmę pierwszeństwa odbierając ją filozofii, od mechaniki oczekiwano rozwiązania wciąż najbardziej palącego problemu - wyjaśnienia ruchu we wszechświecie. [...] Nadzieje, że mechanika stanie się nauką uniwersalną i stworzy system wyjaśniający nie tylko świat przyrody martwej, ale i żywej, były w baroku niezwykle silne. I znów odkrywanie praw rządzących ruchem we wszechświecie, w którym przydatność matematyki była bezsporna, należało do dziedziny rzeczywistości „myślanej”, niewyobrażalnej, choć dającej się sprawdzić przy pomocy obliczeń, a więc jakoś rzeczywistej, faktycznie istniejącej, rządzonej prawami dającymi się wykryć i skontrolować.

Podsumowując dotychczasowe rozważania należy stwierdzić, że zarówno nowe poglądy i krytyka poznania zmysłowego, jak i poznanie rozumowe, wsparte współczesną wiedzą matematyczną, w najogólniejszym sensie, nie sprzyjało tworzeniu wyobrażalnej struktury wszechświata. Wprost przeciwnie, było właściwie kwestionowaniem istnienia tych wszystkich form bytu, z którymi człowiek zżył się od stuleci i uważał je za rzeczywiste ${ }^{30}$.

Niedopowiedzenia pozostawione we wstępie uczona dobitnie uzupełniła w zakończeniu cytowanego studium. Jej stanowisko było jednoznaczne - wyróżniwszy trzy kluczowe jej zdaniem konwencje czy nurty barokowego piśmiennictwa (idyllę, tragizm, fantastykę), wskazywała ich wspólną kulturową motywację: kompensacyjną ucieczkę przed rozpaczą ${ }^{31}$ wywołaną rozpadem starego obrazu świata.

Człowiek baroku, spragniony szczęścia, stałości trwania, krzepiącego poczucia bezpieczeństwa, chciał choć w pewnej mierze uchronić się przed poczuciem totalnej klęski, uciec od niej, by móc mniej więcej normalnie żyć, nie zadręczając się uświadomioną sobie niepewnością istnienia. [...]

A zatem funkcje kompensacyjne były udziałem wszystkich trzech form ucieczki, ukazujących w sytuacjach lub postaciach symbolicznych wyjście z położenia bez wyjścia ${ }^{32}$.

${ }^{30}$ J. Sokołowska, Dwie nieskończoności. Szkice o literaturze barokowej Europy, Warszawa 1978, s. 20-22.

${ }^{31}$ Ibidem, s. 282.

${ }^{32}$ Ibidem, s. 281-283. 
Nacisk wywierany na „universum symboliczne" 33 tradycjonalnej humanistycznej świadomości, po oświeceniowej pauzie - kiedy to udało się w znacznym stopniu przyswoić efekty siedemnastowiecznej rewolucji naukowej i zintegrować je na poziomie światopoglądowym - znów zaczął się wzmagać w wieku XIX.

Jakie formy mogła przybierać reakcja obronna, widać na przykładzie lokalnym, którym jest akademicki konflikt, jaki wyłonił się na północno-wschodnich peryferiach łacińsko-europejskiej ekumeny (pozostających jednak wciąż w jej obrębie, przynajmniej jeśli idzie o elity). Chociaż reformy Komisji Edukacji Narodowej radykalnie unowocześniły kształcenie w zakresie matematyki i nauk empirycznych, dostosowując je do europejskich standardów, to wyraźnie utylitarystyczne nacechowanie programów edukacyjnych Komisji mogło budzić zastrzeżenia, uzasadnione zwłaszcza w odniesieniu do dydaktyki akademickiej. W środowisku wileńskim pierwszych lat XIX w. obiekcje te zaczęły rezonować z późnooświeceniowym neohellenizmem, którego wpływowym reprezentantem stał się w tym środowisku filolog klasyczny Gotfryd Ernest Groddeck, protegowany Czartoryskich, z ich też poręki zatrudniony w Uniwersytecie Wileńskim. „Grodek był przekonany, iż do tego, co wydała kultura starożytna, niewiele można dodać. Myślało tak zresztą wielu hellenistów"34.

Taka postawa wiodła do nieuchronnej kolizji ze stanowiskiem Jana Śniadeckiego, który - będąc daleki od lekceważenia edukacji językowo-filologicznej miał jasną świadomość anachronizmu starożytniczo-humanistycznej ideologii (wikłającej się teraz ponadto w polityczne filiacje z reakcyjnym konserwatyzmem). Postulat ograniczenia wyższej edukacji publicznej do nauki języków i literatury Śniadecki uznawał za niedorzeczny:

[...] bo się nie mogę przekonać, żeby było dobrze uczyć ludzi gadać, a nie myśleć i żeby kto mógł wyniść na gruntownego literata i dobrego pisarza bez rozległych wiadomości z innych nauk i umiejętności czerpanych, bez porządnie wyrobionej i umocowanej refleksji, osobliwie w wieku naszym, kiedy dobre pisanie i mówienie przestało polegać na frazach i figurach retorycznych ${ }^{35}$.

Groddeck z kolei w swej korespondencji z Adamem Kazimierzem i Adamem Jerzym Czartoryskimi - z którymi łączyła go wieloletnia znajomość (w latach 1787-1793 i 1796-1804 pracował w Puławach jako opiekun księgozbioru i nauczyciel synów Adama Kazimierza) - nie szczędził uszczypliwości pod adresem Śniadeckiego:

${ }^{33}$ Termin socjologii wiedzy, powiązany z pojęciem uprawomocnienia, vide P. Berger, T. Luckmann, Społeczne tworzenie rzeczywistości. Traktat z socjologii wiedzy, tłum. J. Niżnik, Warszawa 2010, s. 136-188.

${ }^{34}$ K. Mężyński, Gotfryd Ernest Groddeck, profesor Adama Mickiewicza. Próba rewizji, Gdańsk 1974, s. 52.

${ }^{35}$ J. Śniadecki, List do Adama Jerzego Czartoryskiego z 15 grudnia 1807 r., Bibl. Jagiellońska, rkps 3157, s. 159, cyt. za: K. Mężyński, op. cit., s. 51. 
Unser Rektor glaubt aber nur an die Mathematik als die alleinseligmachende Kirche. Mit allem anderen, meint er, wird's schon gehen [...]. Man glaubt hier, und der Rektor ist gänzlich dieser Meinung, dass die Mathematik den Mangel aller übrigen Kenntnisse vollkommen ersetzt. Es ist kaum begreiflich, wie ein Mann von Kopf und Geist, wie Śniadecki gewiss ist, so höchst einseitig und irrig urteilen $\mathrm{kann}^{36}$.

W istocie spór nie dotyczył ani rzekomego uprzywilejowania matematyki, ani nawet nadmiernie praktycystycznej orientacji nauk matematyczno-przyrodniczych w Uniwersytecie Wileńskim; dotyczył kwestii bardziej zasadniczej:

[...] Grodkowi bynajmniej nie chodzi tu o zmianę charakteru nauczania matematyki. Nie widzi w niej w ogóle wartości. W jego pojęciu matematyka-arytmetyka służy tylko ludzkiej chciwości, cura peculi, którą pogardzał szlachetnie urodzony Ateńczyk, a którą powinien pogardzać również prawdziwy uczony, gdyż i jemu nie przystoi $\beta \alpha v \alpha v \sigma i \alpha$ ['wyrobnictwo' - D.S.]. Grodek nie myślał o zupełnym wyrugowaniu nauk ścisłych, lecz pozostawiał je plebsowi ${ }^{37}$.

Pogląd ten - głoszony przez cenionego, bądź co bądź, filologa - budził konsternację wileńskich przyrodoznawców. Stanisław Jundziłł, wileński profesor botaniki i zoologii (były stypendysta KEN), w swych zapiskach zręcznie obracał przeciw Groddeckowi humanistyczny postulat kultury osobistej, lecz relacjonując jego poglądy, bynajmniej nie przesadzał ${ }^{38}$ :

Profesor ten posiadał gruntowną znajomość nauki, którą miał wykładać; a zaszczepienie i upowszechnienie gustu literatury starożytnej i usposobienie licznych dla szkół nauczycielów są niezaprzeczonym gorliwości jego o pożytek uczniów dowodem. Te jednak główne dobrego profesora przymioty skażone były rażącemi przywarami, które go nieznośnym w Uniwersytecie czyniły.

Trudno sobie wystawić mniej usposobionego do towarzyskiego życia człowieka; trudniej jeszcze pojąć, jak przepędziwszy kilkanaście lat w domu Czartoryskich, w tej sławnej poloru i cywilizacji szkole, nie pozbył się dziczy gminnego pierwiastkowego wychowania. Dumny i zarozumiały, sądził się wyższym nad wszystkich kolegów; krajowców mianowicie, bez względu na talenta i rzetelne w kraju i zawodzie naukowym zasługi, we wszelkich zdarzeniach wzgardliwym przenosił okiem. Napuszony znajomością starożytnych języków i literatury,

${ }^{36}$ G. E. Groddeck, List do Adama Kazimierza Czartoryskiego z 4 sierpnia 1807 r., cyt. za: A. Szantyr, Działalność naukowa Godfryda Ernesta Grodka, w: Z dziejów filologii klasycznej $w$ Wilnie. Studium zbiorowe, Wilno 1937, s. 158-159. (Tłum.: „Nasz rektor wierzy jednak tylko w matematykę jako jedyny Kościół zapewniający zbawienie. Mówi, że reszta się ułoży. Uważa się tutaj, a Rektor jest tego samego zdania, że matematyka w zupełności zastępuje wszystkie inne nauki. Trudno pojąć, jak człowiek takiego umysłu i ducha, jak Śniadecki, może głosić sąd tak jednostronny i błędny").

${ }^{37}$ K. Mężyński, op. cit., s. 50. Skądinąd Groddeckowi o tyle łatwiej przychodziło pogardzać curam peculi, że pobierał najwyższe w całym Uniwersytecie wynagrodzenie.

38 „Badanie dziejów Uniwersytetu dowodnie nas przekonały, że stronniczość Jundziłła nigdy nie szła aż do przeinaczania faktów; te fakta, co on podaje, w zupełności potwierdzają źródła archiwalne; jest on ścisły i wiarygodny. Jedynie oświetlenie jakiegoś szeregu zjawisk lub osób zdarza mu się przejaskrawić [...]" (L. Janowski, W promieniach Wilna i Krzemieńca, Wilno 1923, s. 35). 
te za jedyną nauk zasadę, jedyną potrzebę krajowi poczytywał i lubo nikt ani potrzeby, ani użyteczności ich nie zaprzeczał, ciągle jednak na mniemane ich lekceważenie narzekał. Nie mając najmniejszego dokładnych umiejętności wyobrażenia, wywołanemi je prawie ze szkół mieć życzył i to w Radzie, w szkole i w drukowanych rozprawach głośno utrzymywał. Nie pojmował nawet, jak celujący w wyższym rachunku geometrycznym, fizyce, chemii, historii naturalnej uczniowie naukowymi stopniami zaszczyceni być mogą ${ }^{39}$.

Kuriozalne efekty moralnej paniki, wywołanej akceleracją rozwoju nauk matematyczno-przyrodniczych oraz postępami rewolucji przemysłowej i technicyzacją przestrzeni społecznej - polityczną ekspresją tych lęków był fantazmat pedagogiki hierarchiczno-stanowej ${ }^{40}$ (kształcenia ściśle skorelowanego z klasowym pochodzeniem i statusem ucznia) - podmywały racjonalny fundament humanistycznej tradycji, która i tak, co tu kryć, nigdy egalitarna nie była; tym łatwiej więc w politycznych realiach lat dwudziestych XIX w. zaczęła współbrzmieć z ideologią Świętego Przymierza. Zresztą już wcześniej posłużyła targowiczanom za narzędzie walki z reformami KEN.

5.

Krytyka Diltheyowskiego personalizmu dokonała się w obrębie samej hermeneutyki.

Dla Diltheya pytanie o rozumienie związane było z zagadnieniem innej osoby. Możliwość dosięgnięcia cudzej psychiki przez przeniesienie się do niej stale zajmowała wszystkie nauki o duchu, od psychologii do historii. [...] Warto tu przypomnieć, dlaczego Dilthey postępował w taki właśnie sposób. Postawił on zagadnienie nauk humanistycznych wychodząc od argumentacji Kantowskiej. Wiedza o rzeczach prowadzi do czegoś nieznanego, do rzeczy samej. Ale w przypadku życia psychicznego nie ma rzeczy samej w sobie. Czym jest inny, tym też jesteśmy my sami. Wiedza o życiu psychicznym ma więc niezaprzeczalną wyższość nad wiedzą o przyrodzie. Heidegger, który czytał Nietzschego, nie był już tak naiwny. Wiedział, że inny, tak samo jak ja sam, jest mi bardziej nieznany, niż może być jakiekolwiek zjawisko natury. [...] Jeśli jest jakaś dziedzina bytu, gdzie panuje nieautentyczność, to właśnie w relacjach między dowolną osobą a wszystkimi innymi osobami ${ }^{41}$.

Perspektywa, jaką zarysowują wewnątrzhermeneutyczne rozrachunki, pozostaje wszakże ograniczona i to podwójnie. Pierwsze ograniczenie wynika z właściwego tradycji hermeneutycznej antynaturalizmu; drugie - z czegoś, co można by nazwać samowystarczalnością filozoficznego dyskursu (sam Dilthey potrafił przyznać, że filozofia to „jeden z systemów kultury społeczeństwa ludzkiego" ${ }^{\text {22 }}$ ).

${ }^{39}$ S. Jundziłł, Cudzoziemcy w Uniwersytecie (Urywek pamiętnika ks. Stanisława Jundzitta): Zbiór ułamkowych wiadomości [o osobach i zakładach naukowych $w$ dawniejszym i obecnym (1829 r.) stanie Wileńskiego Uniwersytetu], w: L. Janowski, op. cit., s. 63-64.

${ }^{40}$ Vide K. Mężyński, op. cit., s. 47-48.

${ }^{41}$ P. Ricoeur, op. cit., s. 209.

${ }^{42} \mathrm{~W}$. Dilthey, $O$ istocie filozofii, s. 55. 
Jeżeli kwestia rozwoju samoświadomości humanistycznych dyscyplin i jego metodologicznych konsekwencji ma być traktowana jako zagadnienie przynależne do badań nad historią nauki, trzeba tę perspektywę przekroczyć. Z tego punktu widzenia diagnoza, którą sformułowała Jadwiga Sokołowska w odniesieniu do kluczowych nurtów barokowej kultury literackiej, prezentuje się jako inicjatywa zmierzająca w takim właśnie kierunku. Skądinąd wyjście poza humanistyczny solipsyzm wydaje się najwłaściwszą odpowiedzią na antyhumanistyczne, antysocjologiczne i de facto antynaukowe tendencje, będące efektem ideologii współczesnego scjentyzmu, dla której koncept „fizyka miarą wszechrzeczy” wydaje się tak oczywisty, że nawet nie trzeba go otwarcie głosić. Dlatego też naiwnością jest mniemać, że „antypozytywistyczny przełom” raz na zawsze ustalił ramy humanistycznych dyskursów, ugruntował ich prawomocność i wyznaczył linię demarkacyjną.

Gdy do pozytywnego paradygmatu wiedzy zgłosiły akces nauki społeczne, rezygnując $z$ bycia „naukami moralnymi”, tradycyjne domeny elitarnej kultury umysłowej - filologia i historia, w tym także rodząca się historia sztuki - znalazły się w martwym polu. $\mathrm{Z}$ całą więc ostrością wyłonił się przed nimi problem uprawomocnienia. Ale podczas gdy nauki społeczne nigdy nie obraziły się na przyrodoznawstwo, definiując się jako dyscypliny empiryczne, humanistyka wkroczyła na ścieżkę konfrontacji. Sam termin Geisteswissenschaften mógł zostać sformułowany tylko po niemiecku, bo tylko niemiecka myśl filozoficzna zapewniała wówczas pojęciową prawomocność terminu Geist. Dosłowny francuski odpowiednik *sciences d'Esprit wyglądałby niepoważnie, zważywszy na konotacje rzeczownika l'esprit, którego dobrym odpowiednikiem był do początków XIX w. polski „dowcip”. Niemiecki tytuł dzieła Chateaubrianda Der Geist des Christentums odpowiadał oryginalnemu Le Génie du Christianisme. Po angielsku też byłoby ciężko: obok rodzimego anglosaskiego ghost (hālige gāstas 'święte duchy' poświadczone w staroangielskim poemacie Sen o krzyżu) funkcjonował zapożyczony spirit (jeszcze w siedemnastowiecznej Biblii Króla Jakuba Holy Ghost i Holy Spirit występują obocznie, ten drugi znacznie rzadziej). Lecz angielska poezja od dawna lubowała się w wywoływaniu właśnie zlatynizowanych duchów niższej konduity, także na scenach operowych (np. aria sopranowa „Ye Gentle Spirits of the Air, appear; / Prepare, and joyn your tender Voices here" z III aktu The Fairy-Queen Henry'ego Purcella). Niemieckiego „ducha” język polski przyswoił dość szybko, choć jeszcze u pierwszych odbiorców Ody do młodości zdanie „Wyjdzie z zamętu świat ducha” ${ }^{43}$ („Geisterwelt” - zanotował Mickiewicz w autografie) budziło

${ }^{43}$ A. Mickiewicz, Oda do młodości, w: idem, Dzieła wszystkie, t. 1: Wiersze, cz. 1, red. K. Górski, Wrocław-Warszawa-Kraków 1972, w. 69, s. 93. Świadectwem niemieckiej (Schillerowskiej w tym przypadku) proweniencji pewnych rozwiązań zastosowanych w Odzie do młodości jest nawet grafia - w pierwszej wersji tekstu Mickiewicz posłużył się jeszcze złożeniami „świat-rzeczy” i „świat-ducha” (ibidem, w. 63, 69, s. 91). 
mieszane uczucia: Franciszek Malewski perswadował autorowi, że „dotąd »duch « u nas nic nie ma platońskiego, owszem, zawsze jest upiorowaty" ${ }^{\prime 4}$.

Jest więc dość znamienne, że gdy tylko „nauki o duchu” przekraczały granice Germanii, od razu przeistaczały się w stare, dobre humaniora - 'nauki o rzeczach ludzkich' (ang. Humanities, fr. Sciences humaines), ale teraz już wyposażone w odświeżoną tożsamość i świadome swej misji, wobec czego i Niemcy postanowili wyrównać do szeregu (humanistische Studien). Patrząc od strony czysto terminologicznej, trudno sie powstrzymać od uwagi, że racjonalizację uduchowienia jako przedmiotu wiedzy osiągnięto tu niewygórowanym kosztem.

Wszystko staje się bardziej klarowne, gdy „ukryte intencje” tak zwanego przełomu antypozytywistycznego zrekonstruować następująco: Chodziło w nim nie tyle o uduchowienie przedmiotu, co o jego dematerializację - równoważną usunięciu go raz na zawsze z pola zainteresowania aroganckich „scjentystów”, ewidentnie szukających zwady. W obrębie nauk humanistycznych wolno więc było i wolno nadal, w rozsądnych granicach, spierać się o to, czym one właściwie są, pod warunkiem zachowania konsensu w kwestii: czym na pewno nie są, nie były i do skończenia świata - nie będą. W efekcie współczesny socjolog nie może się obejść bez znajomości zaawansowanej statystyki matematycznej, współczesny psycholog bez znajomości fizjologii etc., natomiast współczesny historyk literatury może bez trudu prosperować metodologicznie niby homo bulla, przy czym bywa to bańka z pancernego szkła.

Podejmując tezę Jadwigi Sokołowskiej o skutkach siedemnastowiecznej rewolucji naukowej dla ówczesnej kultury humanistycznej i traktując przedstawione przez uczoną wnioski jako narzędzie typologiczne, możemy te barokowe perturbacje ujrzeć jako początek procesu sfinalizowanego w drugiej połowie XIX w. Jeśli ujmiemy to continnum jako dwa powiązane zbiory danych, wówczas, po wprowadzeniu fragmentu pewnego tekstu poezji romantycznej (Marii Antoniego Malczewskiego ${ }^{45}$ ) w charakterze ogniwa pośredniego, zyskujemy możliwość oddania historycznokulturowej motywacji „przełomu antypozytywistycznego” za pomocą amplifikacyjnej parafrazy, hiperbolizując temat do barokowego poziomu:

„Bo w mojej zwiędłej twarzy zamieszkała bladość,

Bo w mej zdziczałej duszy wypleniono radość,

Bo wpływ mego Anioła grób w blasku zobaczy”.

„To czegoż chcesz, Diltheyu?” - „Uciec od Rozpaczy”.

Oczywiście, ten retorycznie przejaskrawiony obraz nie jest „prawdziwy” w tym sensie, że taki wizerunek nie jest zgodny z wizerunkiem, jak by to można

${ }^{44}$ Cyt. za: W. Billip, Mickiewicz w oczach wspótczesnych. Dzieje recepcji na ziemiach polskich w latach 1818-1830. Antologia, Wrocław 1962, s. 321.

${ }^{45}$ A. Malczewski, Maria, oprac. R. Przybylski, Wrocław-Kraków 1958, w. 671-674, s. 38. 
nazwać, Diltheya filozofów, Diltheya od „logosu życia”, Diltheya efektywnie obchodzącego restrykcje Kantowskiego transcendentalizmu i rozpraszającego Heglowski fantazmat wiedzy absolutnej, Diltheya twórcy krytyki rozumu historycznego. Niemniej ta heurystyczna parafraza pozwala poprzez realną analogię uchwycić związek genetyczny - i w tym sensie jest nawet zgodna z Diltheyowską ideą rozumienia jako procesu.

„Literatura zwłaszcza - pisała Sokołowska - po raz pierwszy w sposób tak jednoznaczny została obarczona poważnym obowiązkiem dania odpowiedzi na podstawowe pytania dotyczące ludzkiej egzystencji. Dotychczas tej odpowiedzi oczekiwano od religii i filozofii" ${ }^{46}$. W drugiej połowie XIX w., już po odkryciu elektromagnetyzmu, wachlarz środków kompensacyjnych z powodzeniem poszerzyła Diltheyowska hermeneutyka, jeśli nawet stało się to wbrew intencjom samego Diltheya.

Racjonalizująca intencja ustanowienia „nauk o duchu” jako niezależnego zespołu dyscyplin, zgłaszających już na wstępie dyplomatyczne désintéressement względem działań prowadzonych w domenie przyrodoznawstwa i rodzących się nauk społecznych - na mocy zasady: oni wszystko wiedzą, ale niczego nie rozumieją - została zrealizowana w trybie raczej symbolicznym niż pojęciowym; jej efekt nazbyt przypominał operację typu magicznego, wedle wzorca „Klęto ducha - klątwy słucha” ${ }^{47}$. „Dramat - powiada Dilthey - powstaje dzięki specyficznemu powiązaniu materiału, motywów, fabuły, nastroju poetyckiego, środków artystycznego wyrazu. Każdy z tych momentów współdziała w strukturze dzieła, a działania te są powiązane ze sobą wewnętrznym prawem poezji”"48. Właściwa nauka o literaturze zaczęła się, gdy jej przedmiotem stało się właśnie to „wewnętrzne prawo poezji”, którym zaplanowana przez Diltheya humanistyka, powołana wszak do wyższych celów, w ogóle nie miała się zajmować.

\section{Bibliografia}

Antologia liryki angielskiej, oprac. J. Pietrkiewicz, Warszawa 1987.

Berger, Peter, Luckmann, Thomas, Społeczne tworzenie rzeczywistości. Traktat z socjologii wiedzy, thum. J. Niżnik, Warszawa 2010.

Billip, Witold, Mickiewicz w oczach wspótczesnych. Dzieje recepcji na ziemiach polskich w latach 1818-1830. Antologia, Wrocław 1962.

${ }^{46}$ J. Sokołowska, op. cit., s. 20.

${ }^{47}$ A. Mickiewicz, Ucieczka, w: idem, Dzieła wszystkie, t. 1: Wiersze, cz. 3, red. K. Górski, Wrocław-Warszawa-Kraków 1972, w. 37, s. 13.

${ }^{48}$ W. Dilthey, [Określenie „nauk o duchu”], s. 188. 
Brogowski, Leszek, Świadomość i historia. Studium o filozofii Wilhelma Diltheya, Gdańsk 2004.

Dilthey, Wilhelm, O istocie filozofii, tłum. E. Paczkowska-Łagowska, Warszawa 1987.

Dilthey, Wilhelm, Pisma estetyczne, thum. K. Krzemieniowa, oprac. Z. Kuderowicz, Warszawa 1982.

Janowski, Ludwik, W promieniach Wilna i Krzemieńca, Wilno 1923.

Kuderowicz, Zbigniew, Dilthey, Warszawa 1987.

Lorenc, Włodzimierz, Filozofia życia Wilhelma Diltheya, „Sztuka i Filozofia” 2005, t. 27.

Malczewski, Antoni, Maria, oprac. R. Przybylski, Wrocław-Kraków 1958.

Markowska, Martyna, Interpretacja jako rozumienie w ujęciu Wilhelma Diltheya, „Czasopismo Filozoficzne" 2007, nr 2.

Mężyński, Kazimierz, Gotfryd Ernest Groddeck, profesor Adama Mickiewicza. Próba rewizji, Gdańsk 1974.

Mickiewicz, Adam, Dzieła wszystkie, t. 1: Wiersze, cz. 1, red. K. Górski, Wrocław-Warszawa-Kraków 1972.

Paczkowska-Łagowska, Ewa, Logos życia. Filozofia hermeneutyczna w kręu Wilhelma Diltheya, Gdańsk 2000.

Psillos, Stathis, Scientific Realism. How science tracks truth, London-New York 2005.

Ricoeur, Paul, Język, tekst, interpretacja. Pisma wybrane, tłum. P. Graff, K. Rosner, Warszawa 1989.

Sarbiewski, Maciej Kazimierz, Dii gentium. Bogowie pogan, tłum. K. Stawecka, Wrocław-Warszawa-Kraków 1972.

Seweryn, Dariusz, Alegoria i problemy dyskursu symbolicznego, Lublin 2017.

Słowacki, Juliusz, Beniowski, w: idem, Dzieła wszystkie, t. 5, red. J. Kleiner, Wrocław 1954.

Snow, Charles Percy, Dwie kultury, tłum. T. Baszniak, Warszawa 1999.

Sokołowska, Jadwiga, Dwie nieskończoności. Szkice o literaturze barokowej Europy, Warszawa 1978.

Szantyr, Antoni, Działalność naukowa Godfryda Ernesta Grodka, w: Z dziejów filologii klasycznej w Wilnie. Studium zbiorowe, Wilno 1937.

DARIUSZ SEWERYN - prof. dr hab. Zatrudniony w Katedrze Literatury Oświecenia i Romantyzmu KUL. Autor książek Alegoria i problemy dyskursu symbolicznego (2017); Innowacja i tradycja. Studia i szkice o poezji romantycznej (2014); Prehistoria - średniowiecze - romantyzm. W kręgu indoeuropejskich tematów mitologicznych: od Dumézila do Stowackiego (2014); Słowacki nie-mistyczny (2001), „,...Jak tam zaszedteś...?”. Mickiewicz w szkole klasycznej (1997); O wyobraźni lirycznej Adama Mickiewicza (1996). 